\title{
NietzSche AND ZION
}





\title{
NietZSGHE AND Zion
}

\section{JaCOB Golomb}

\author{
CORNELL UN IVERSITY PRESS
}

Ithaca and London 
Copyright () 2004 by Cornell University

All rights reserved. Except for brief quotations in a review, this book, or parts thereof, must not be reproduced in any form without permission in writing from the publisher. For information, address Cornell University Press, Sage House, $5_{1} 2$ East State Street, Ithaca, New York $14^{8} 5^{\circ}$.

First published 2004 by Cornell University Press

Printed in the United States of America

Library of Congress Cataloging-in-Publication Data

Golomb, Jacob.

Nietzsche and Zion / Jacob Golomb.

p. $\mathrm{cm}$.

Includes bibliographical references and index.

ISBN o-8014-3762-8 (cloth : alk. paper)

1. Zionism-Philosophy. 2. Nietzsche, Friedrich Wilhelm, 1844-1900Influence. 3. Philosophy, Jewish. I. Title.

$\mathrm{DS}_{14} 49 \cdot \mathrm{G}_{5492} 2004$

$320.54^{\prime} 095694-\mathrm{dc} 22$

2003019238

Cornell University Press strives to use environmentally responsible suppliers and materials to the fullest extent possible in the publishing of its books. Such materials include vegetable-based, low-VOC inks and acid-free papers that are recycled, totally chlorine-free, or partly composed of nonwood fibers. For further information, visit our website at www.cornellpress.cornell.edu.

$\begin{array}{lllllllllll}\text { Cloth printing } & 10 & 9 & 8 & 7 & 6 & 5 & 4 & 3 & 2 & 1\end{array}$ 
For Margit 
